\title{
Pengaruh Bermain CD Interaktif Edukatif 'Ayo Belajar' Terhadap Kemampuan Kognitif Anak Usia 5-6 Tahun Di TK Mentari Cipondoh Tangerang
}

\author{
${ }^{1}$ Umu Atiyah, ${ }^{2}$ Faisal Ibrahim \\ 1,2Program Studi Pendidikan Guru Pendidikan Anak Usia Dini; Fakultas \\ Keguruan Dan Ilmu Pendidikan; Universitas Muhammadiyah Tangerang \\ 1atiyah.tiya@gmail.com, 2faisal_ibrahim8586@yahoo.com
}

\begin{abstract}
Abstrak
Tujuan dalam penelitian ini adalah untuk mengetahui perbedaan kemampuan kognitif antara siswa yang diberi metode pembelajaran menggunakan media CD interaktif dengan siswa yang diberi metode pembelajaran konvensional di TK Mentari Cipondoh Tangerang. Metode penelitian yang digunakan adalah Eksperimen.Sampel yang diambil untuk mewakili populasi adalah menggunakan teknik simple random sampling. Sampel penelitian adalah siswa kelas B TK Mentari sebanyak 10 siswa. Teknik pengumpulan data yang digunakan adalah observasi, dokumentasi, pretest dan posttest. Uji Prasyarat analisis menggunakan uji Chi Kuadrat dan Uji Fisher, diperoleh bahwa kedua sampel berdistribusi normal dan homogen. Dari perhitungan uji statistik diperoleh thitung $>$ tabel $(2,834>2,306)$, maka $H_{o}$ ditolak dan $\mathrm{H}_{a}$ diterima pada taraf signifikan $\mathrm{a}=0,05$ dengan derajat kebbasan $(\mathrm{db})=8$. Sehingga dapat disimpulkan bahwa terdapat perbedaan kemampuan kognitif siswa yang diberikan metode pembelajaran menggunakan media CD interaktif dengan metode pembelajaran konvensional. Dengan demikian dapat disimpulkan bahwa kemampuan kognitif siswa kelas B yang belajar dengan menggunakan media pembelajaran CD interaktif lebih baik dari siswa kelas $B$ yang belajar tanpa menggunakan media CD interaktif.
\end{abstract}

Kata Kunci : Kognitif, CD Interaktif Edukatif, Usia 5-6 Tahun.

\section{Pengantar}

Proses pembelajaran adalah sebuah bentuk pelaksanaan pendidikan yang memiliki banyak komponen yang saling terkait didalamnya agar dapat meningkatkan seluruh aspek pertumbuhan dan proses para peserta didik, di antaranya adalah tujuan pembelajaran, materi pembelajaran, media pembelajaran 
"Ceria"

Jurnal Program Studi Pendidikan Anak Usia Dini

evaluasi. Berdasarkan pada seluruh komponen tersebut, maka seharusnya pelaksanaan pendidikan yang dilaksanakan di setiap sekolah atau di lembaga pendidikan manapun menjadi lebih berkualitas dan sangat mudah untuk diaplikasikan, salah satunya lembaga PAUD.

Pada penyelenggaraan lembaga PAUD, guru berperan sebagai pendidik, tidak hanya harus mempertimbangkan seluruh komponen dalam proses pembelajaran untuk mengembangkan seluruh aspek proses peserta didik. Selain itu, guru juga mempertimbangkan kebutuhan standar pertumbuhan dan proses serta keunikan yang dimiliki oleh setiap individu anak peserta didik. Hal tersebut penting karena sebagai karakteristik diri dari setiap individu, akan sangat menentukan kesiapan dalam melaksanakan kegiatan pembelajaran.

Anak usia dini dalam masa prosesnya sedang berada pada tahap yang penting karena anak sudah mampu menerima keterampilan dan pengajaran sebagai dasar pengetahuan dan proses berpikir. Pengaruh lingkungan awal pada proses otak akan berdampak lama. Oleh karena itu, anak yang mendapat stimulasi lingkungan yang baik, fungsi otaknya akan berkembang dengan lebih baik pula.

Hal ini dapat diartikan bahwa setiap anak memiliki caranya sendiri dalam mengamati dan mengartikan setiap hal yang terjadi disekitar mereka. Anak usia dini yang berada pada tahap praoperasional mengalami peningkatan kognitif dalam prosesnya untuk dapat mengolah dan memproses informasi yang berasal dari sumber informasi yang nyata atau konkret.

Peningkatan proses kognitif ini dilakukan agar mereka dapat mengolah dan memproses informasi yang ada disekitar mereka ataupun materi yang sedang dibahas di kelas sehingga dapat menghasilkan respon yang tepat terhadap informasi tersebut, para peserta didik juga menjadi lebih terbiasa untuk dapat menggunakan setiap informasi yang didapatnya menjadi sesuatu yang lebih bermakna dan lebih bermanfaat. Respon tersebut dapat ditunjukkan melalui prosesnya dalam mengingat kembali informasi yang pernah di dapat 
"Ceria"

Jurnal Program Studi Pendidikan Anak Usia Dini

sebelumnya, memahami konsep atau makna dari informasi tersebut, menggunakan informasi untuk mengembangkan pengetahuan, dan menganalisis setiap informasi menjadi bagian-bagian yang saling terkait.

Upaya melatih kemampuan kognitif anak, dalam aktivitas bermain menggunakan CD interaktif edukatif termasuk ke dalam jenis kegiatan bermain dengan aturan karena bermain menggunakan aturan maka akan melatih kemampuan kognitif anak. Peran aktif anak dalam melewati serangkaian proses pembelajaran yang telah dirancang oleh guru, para siswa diberikan stimulasi untuk dapat memproses informasi mengenai materi yang sedang dibahas dengan penggunaan alat dan media pembelajaran yang disesuaikan karakteristik proses peserta didik, dalam hal ini siswa kelas TK B yang membutuhkan alat dan media pembelajaran yang bersifat konkret atau nyata. Pada tahap ini anak usia dini belum mampu berpikir secara abstrak sehingga dibutuhkan media atau alat pembelajaran yang nyata untuk menstimulasi proses penyusunan pengetahuan yang akan mereka dapatkan sebagai sebuah informasi baru dalam kehidupan mereka.

Peran guru sebagai pendidik adalah pembimbing dan fasilitator dalam pembelajaran. Guru tidak lagi banyak menggunakan pola belajar dengan tipe auditori yang terlalu banyak menggunakan bahasa verbal dalam proses belajar. Namun pada kenyataannya, dari hasil laporan penelitian mengenai tingkat proses kognitif anak usia dini di Indonesia oleh Unit Pendidikan Kantor Bank Dunia Jakarta, didapatkan hasil bahwa tingkat kelemahan yang dimiliki anak usia dini di Indonesia menyangkut proses kognitifnya adalah sebesar $80 \%$ dibandingkan negara Filipina dengan tingkat kelemahan sebesar $70 \%$ (http://datatopics.worldbank.org/hnp/file/edstats/IDN10b.pdf).

Hal ini ditandai dengan rendahnya proses anak dalam melakukan kegiatan membaca dan mengenali angka. Masih menurut survey hal tersebut didasarkan pada praktik pengasuhan, pendidikan, dan pekerjaan orang tua. Hanya sekitar 
"Ceria"

Jurnal Program Studi Pendidikan Anak Usia Dini

$20 \%$ anak-anak Indonesia yang mendapatkan stimulus yang baik untuk meningkatkan proses kognitif mereka.

Berdasarkan survey tersebut didapatkan hasil yang konsisten terhadap kelemahan kognitif pada anak-anak Indonesia. Menurut Sudjiono (2013, h. 6.30) pada anak usia 5-6 tahun bahwa kemampuan yang diharapkan dalam aspek perkembangan kognitif yaitu mampu untuk memecahkan masalah sederhana dalam kehidupan sehari-hari, menyebutkan semua jenis bentuk, mencocokkan bilangan dengan lambang bilangan, mengklasifikasikan benda berdasarkan warna bentuk dan ukuran, mengenal perbedaan berdasarkan ukuran "lebih dari", "kurang dari" "paling/ter", mengklasifikasikan benda yang lebih banyak ke dalam kelompok yang sama atau kelompok yang sejenis, mengurutkan benda berdasarkan ukuran, mengklasifikasikan benda berdasarkan fungsi, mengenal sebab akibat, menunjukan inisiatif, menunjukan aktivitas yang bersifat eksploratif dan menyelidik, menyusun perencanaan kegiatan apa yang akan dilakukan, memahami konsep matematika sederhana.

Melalui pengamatan yang peneliti lakukan pada anak usia 5-6 tahun kelompok B1 dan B2 berjumlah masing-masing 5 anak di TK Mentari pada hari Senin 21 Maret 2016, anak yang telah mencapai indikator memecahkan masalah sederhana yaitu baru 2 anak yang dapat memecahkan masalah, 6 anak yang dapat mengenal bilangan dengan lambang bilangan, 6 anak yang bisa menyebutkan bentuk geometri, 4 anak yang dapat mengurutkan pola, 5 anak yang memahami konsep matematika sederhana.

Berdasarkan permasalahan di atas peneliti mencari upaya dalam pemecahan masalah tersebut dengan menggunakan media CD Interkatif edukatif. Media CD Interaktif merupakan mdia yang dikemas semenarik mungkin yang berupa CD berisikan materi pembelajaran anak yang sesuai dengan kemampuan kognitif anak usia 5-6 tahun.

Kemampuan berasal dari kata mampu yang berarti kuasa (bisa, sanggup) melakukan sesuatu, sedangkan kemampuan berarti kesanggupan, kecakapan, 
"Ceria"

\section{Jurnal Program Studi Pendidikan Anak Usia Dini}

kekuatan (KBBI). Kemampuan adalah suatu kesanggupan dalam melakukan sesuatu. Seseorang dikatakan mampu apabila ia bisa melakukan sesuatu yang harus ia lakukan.

Kemampuan yang dimiliki oleh manusia merupakan bekal yang sangat pokok. Kemampuan ini telah dimiliki sejak lahir untuk mencapai perkembangan. Sejalan dengan hal tersebut kemampuan (ability) berarti kapasitas seorang individu untuk melakukan beragam tugas dalam suatu pekerjaan. (Robbins \& Judge, 2008, h.57). Jadi kemampuan ialah sebuah penilaian terkini atas apa yang dapat dilakukan seseorang.

Setiap individu memiliki kemampuan yang berbeda-beda dalam melakukan suatu tindakan. Kemampuan adalah bakat seseorang untuk melakukan tugas fisik atau mental (Ivanchevich dkk, 2005, h. 85). Jadi kemampuan ini mempengaruhi potensi yang ada dalam diri individu tersebut. Kemampuan besar pengaruhnya terhadap kemajuan belajar.

Berdasarkan pengertian tersebut dapat disimpulkan bahwa kemampuan adalah kesanggupan atau kecakapan seorang individu dalam menguasai suatu keahlian dan digunakan untuk mengerjakan beragam tugas dalam suatu pekerjaan.

Kognitif merupakan salah satu aspek perkembangan yang berkaitan dengan bagaimana individu mempelajari dan memikirkan lingkungannya. Menurut Myers dalam Desmita (2008, h. 103), "cognition refers to all the mental activities associated with thinking, knowing, remembering." Kognisi mengacu pada semua aktivitas mental yang berhubungan dengan pemikiran, pengetahuan dan mengingat.

Pengertian yang hampir senada juga diberikan oleh Matlin dalam Desmita (2008, h. 103), yaitu: "cognition, or mental activity, involves the acquisition, storage, retrieval, and use of knowledge." Kognisi atau aktivitas mental, melibatkan penerimaan, penyimpanan, pencarian, dan penggunaan pengetahuan. 
"Ceria"

Jurnal Program Studi Pendidikan Anak Usia Dini

Terkait dengan kegiatan pembelajaran, menurut pendapat Maynard dan Thomas di atas, istilah kognitif seringkali digunakan sebagai sebuah istilah untuk sebuah bentuk proses berpikir anak-anak dalam upaya memahami kegiatan yang diberikan oleh guru. Proses mental yang terjadi pada anak-anak adalah berupa persepsi, perhatian, kebahasaan dan mengingat.

Proses yang diungkapkan oleh Maynard dan Thomas juga didukung oleh Robson (2006, h.21), ia juga mengungkapkan, “...there is an emphasis on cognition as largely a matter of handing information to solve problems, with a focus on what mental processes are used to deal with information, how they are organized and how they change during learning or development.". Ada penekanan pada kognisi sebagai "suatu hal yang digunakan dalam penggunaan informasi untuk memecahkan masalah', dengan fokus pada proses mental yang mana digunakan untuk menangani informasi tersebut, bagaimana mereka dapat terorganisir dan berubah selama pembelajaran atau perkembangan.

Pada uraian yang sudah dijelaskan, Robson (2006, h. 21) menyebutkan bahwa perkembangan kognitif setiap anak tergantung kepada proses mental yang digunakan dalam upaya menyusun, menggunakan, dan mengembangkan informasi yang didapat untuk memecahkan setiap masalah yang ada. Proses mental tersebut dapat berkembang dengan baik sehingga memiliki sistem kerja yang baik pula apabila dalam rentang waktu perkembangannya selalu mendapatkan stimulasi yang tepat.

Mengembangkan kemampuan kognitif anak harus melalui beberapa tahap. Menurut Chaplin yang dikutip Desmita (2008, hal. 103), dijelaskan bahwa kognitif adalah istilah umum yang mencakup semua bentuk pengenal, termasuk didalamnya mengamati, melihat, memperhatikan, memberikan, menyangka, membayangkan, memperkirakan, menduga dan menilai. Jadi kognitif adalah bentuk proses berpikir anak dalam mengamati lingkungan sekitarnya, karena anak memiliki rasa ingin tahu yang kuat terhadap segala sesuatu terutama yang menarik minatnya. 
"Ceria"

Jurnal Program Studi Pendidikan Anak Usia Dini

Jadi dari beberapa pendapat di atas disimpulkan bahwa kemampuan kognitif adalah penampilan yang dapat diamati dari aktivitas mental untuk memperoleh pengetahuan melalui pengalaman sendiri. Selanjutnya dalam penelitian ini peneliti membatasi kemampuan siswa yang menjadi tolak ukur ranah kognitif yang meliputi memecahkan masalah sederhana dalam kehidupan sehari-hari, memahami konsep matematika sederhana, dapat mengenal bilangan, dan dapat mengenal bentuk geometri.

Untuk mengetahui pengertian bermain CD Interaktif ada beberapa pendapat diantaranya Piaget dalam Sujiono (2010, h. 34) mengatakan bahwa bermain adalah suatu kegiatan yang dilakukan berulang-ulang dan menimbulkan kesenangan/kepuasan bagi diri seseorang, sedangkan Parten (Sujiono, 2010, h. 34) memandang kegiatan bermain sebagai sarana sosialisasi di mana diharapkan melalui bermain dapat memberi kesepakatan anak bereksplorasi, menemukan, mengekspresikan perasaan, berkreasi, dan belajar secara menyenangkan.

Menurut Vygotsky (Montolalu dkk, 2008, h. 1.14) bermain memiliki peranan langsung dalam perkembangan kecerdasan (kognitif) anak, yaitu dengan cara bermain simbolis. Bermain merupakan kesempatan bagi anak untuk bereksplorasi, mengadakan penelitian-penelitian, mengadakan percobaanpercobaan untuk memperoleh pengetahuan.

Multimedia interaktif (Daryanto, 2012, h. 53) adalah suatu multimedia yang dilengkapi dengan alat pengontrol yang dapat dioperasikan oleh pengguna sehingga pengguna dapat memilih apa yang dikehendaki untuk proses selanjutnya. Multimedia ini berguna untuk menyalurkan pesan serta dapat merrangsang pilihan, perasaan, perhatian dan kemauan siswa sehingga secara sengaja proses belajar terjadi, bertujuan dan terkendali.

Pemanfaatan komputer untuk pendidikan yang dikenal sering dinamakan pembelajaran dengan bantuan komputer (CAI) dikembangkan dalam beberapa format, antara lain drills and practice, tutorial, simulasi, permainan, dan discovery (Arsyad, 2011, h.54). Pemanfaatan tersebut sangat membantu guru dalam 
"Ceria"

Jurnal Program Studi Pendidikan Anak Usia Dini

membuat media pembelajaran untuk anak usia dini, karena sangat membantu guru dalam melakukan kegiatan pembelajaran bersama anak dikelas.

Dapat kita simpulkan bahwa bermain CD Interaktif adalah bermain menggunakan media dengan penyimpanan file dengan format aplikasi interaktif didalamnya yang berisi latihan, tutorial dan simulasi permainan. Secara keseluruhan dapat kita simpulkan definisi bermain CD Interaktif adalah bermain yang menggunakan media dengan sebuah format multimedia dapat dikemas dalam sebuah CD (Compact Disk) dengan tujuan aplikasi interaktif di dalamnya berisi menu-menu yang dapat dipilih dengan cara mengklik tombol pada layar monitor untuk menampilkan sebuah informasi tertentu.

\section{Metode}

Metode yang digunakan dalam penelitian ini adalah Quasi Experimental Design. Desain ini, mempunyai kelompok kontrol, tetapi tidak dapat berfungsi sepenuhnya untuk mengontrol variabel-variabel luar yang mempengaruhi pelaksanaan eksperimen (Sugiyono, 2015, h. 114).

Desain penelitian yang digunakan adalah kelompok Nonequivalent Control Geoup Desaign. Dalam penelitian ini terdapat dua kelompok kelas yaitu kelompok eksperimen dan kelompok kontrol. Pada kelompok eksperimen diberikan treatment (perlakuan) berupa pembelajaran dengan menggunakan media CD Interaktif, sedangkan kelompok kontrol tidak diberikan treatment. Sebelumnya kedua kelompok tersebut diberikan pretest untuk mengetahui keadaan awal adakah perbedaan antara kelompok eksperimen dengan kelompok kontrol.

Waktu Pelaksanaan penelitian ini adalah semester II tahun pelajaran 2015/2016, bulan April sampai dengan Mei 2016. Populasi penelitian adalah seluruh siswa kelas B TK Mentari Cipondoh Kota Tangerang yang berjumlah 10 siswa, sedangkan sampel penelitian adalah siswa kelompok B sebanyak 10 siswa dengan menggunakan sampel jenuh untuk anaknya. Dengan dipilih dua kelas, satu kelas menjadi kelas eksperimen dengan diterapkan bermain dengan 
"Ceria"

Jurnal Program Studi Pendidikan Anak Usia Dini

menggunakan media CD Interkatif dan satu kelas lain dengan pembelajaran konvensional.

Pengambilan sampel pada penelitian ini dilakukan dengan teknik simple random sampling yaitu responden yang terpilih menjadi anggota sampel diambil secara acak tanpa memperhatikan strata yang ada. Pengumpulan data pada penelitian ini menggunakan teknik:

a) Observasi

b) Dokumentasi

c) Pretest dan Posttest

Data yang diperoleh dianalisis dengan analisis deskriptif. Pengujian validitas kemampuan kognitif menggunakan rumus korelasi product moment. Untuk uji validitas empirik menggunakan item total dengan reliabilitas menggunakan teknik alfa cronbach. Pengujian hipotesis penelitian yang diajukan menggunakan teknik analisis varians. Namun, sebelum pengujian hipotesis terlebih dahulu dilakukan uji prasyarat penelitian yaitu uji normalitas dan homogenitas. Pengujian normalitas menggunakan uji liliefors dan homogenitas menggunakan uji fisher dengan taraf signifikansi $a=0,05$.

\section{Hasil dan Pembahasan}

Berdasarkan hasil perhitungan uji normalitas menggunakan uji Liliefors dapat ditarik kesimpulan bahwa Lmax kelompok eksperimen lebih kecil dari Ltabel, pada taraf signifikansi a=0,05, menurut kriteria normalitas jika $L_{\max }<$ Ltabel maka $\mathrm{H}_{\mathrm{o}}$ diterima, sehingga berdasarkan kriteria pengujian maka sampel berdistribui normal. Demikian juga kelompok kontrol, nilai Lmax kelas kontrol lebih kecil dari Ltabel maka $\mathrm{H}_{\mathrm{o}}$ diterima, sehingga berdasarkan kriteria pengujian maka sampel berdistribusi normal.

Berdasarkan pada hasil perhitungan uji homogenitas menggunakan uji Fisher, dapat dilihat bahwa Fhitung lebih kecil dari $F_{\text {tabel }}(1,01<6,39)$, menurut 
"Ceria"

Jurnal Program Studi Pendidikan Anak Usia Dini

kriteria homogenitas jika Fhitung $<\mathrm{F}_{\text {tabel }}$ maka $\mathrm{H}_{\mathrm{o}}$ diterima, sehingga berdasarkan kriteria pengujian maka varians kedua sampel homogen.

Pengujian hipotesis uji rata-rata dua pihak menggunakan rumus uji $t$ Polled Varians, dengan taraf signifikansi 5\%, dari hasil perhitungan nilai pretest kedua kelompok diperoleh nilai thitung lebih kecil dari nilai tabel $(2,077<2,306)$ maka $\mathrm{H}_{\mathrm{o}}$ diterima, sehingga berdasarkan kriteria pengujian maka tidak terdapat perbedaan rata-rata nilai pre-test yang signifikan antara kelompok eksperimen dan kelompok kontrol sedangkan pada penilaian posttest kedua kelompok diperoleh nilai thitung lebih besar dari nilai tabel $(2,834>2,306)$ maka $H_{0}$ ditolak, sehingga berdasarkan kriteria pengujian maka terdapat perbedaan rata-rata nilai post-test yang signifikan antara kelompok eksperimen yang diberi perlakuan dengan media CD Interaktif Edukatif dan kelompok kontrol yang tidak diberikan perlakuan/pembelajaran konvensional. Dengan demikian dapat disimpulkan bahwa ada peningkatan yang nyata kemampuan kognitif dengan menggunakan pembelajaran media CD interaktif.

Berdasarkan pengujian hipotesis di atas menunjukkan bahwa pada nilai pre-test tidak terdapat perbedaan kemampuan kognitif siswa yang signifikan antara kelompok eksperimen dan kelompok kontrol sebelum diberi perlakuan. Dimana diperoleh nilai thitung 2,171 < tabel 2,306, ini menunjukkan tidak terdapat perbedaan yang signifikan antara kelompok eksperimen dan kelompok kontrol. Tes ini dilakukan untuk membandingkan kemampuan kognitif siswa setelah mendapatkan pelakuan. Pengujian yang kedua yaitu untuk menguji hasil post-test kemampuan kognitif dengan metode pembelajaran konvensional dan metode pembelajaran menggunakan media CD interaktif, diperoleh nilai thitung 6,199 $>$ ttabel 2,306. Hasil uji menunjukkan ada perbedaan signifikan antara kemampuan kognitif dengan metode pembelajaran konvensional dan metode pembelajaran menggunakan media CD interaktif.

Menurut Vygotsky (Montolalu dkk, 2008, h. 1.14) bermain memiliki peranan langsung dalam perkembangan kecerdasan (kognitif) anak, yaitu dengan 
"Ceria"

\section{Jurnal Program Studi Pendidikan Anak Usia Dini}

cara bermain simbolis. Bermain merupakan kesempatan bagi anak untuk bereksplorasi, mengadakan penelitian-penelitian, mengadakan percobaanpercobaan untuk memperoleh pengetahuan. Seperti yang diungkapkan oleh Vygotsky pada metode pembelajaran konvensional itu semua tidak dapat dilakukan oleh siswa, siswa tidak aktif serta kesulitan dalam mengenal konsep bilangan dan belum dapat menyelesaikan permasalahan sederhana, namun setelah diberikan perlakuan dengan metode pembelajaran menggunakan CD interaktif mendapatkan hasil yang lebih baik dari metode konvensional. Dengan demikian menunjukkan ada perbedaan kemampuan kognitif yang signifikan antara kelompok yang mendapatkan metode pembelajaran media CD interaktif dengan kelompok yang tidak mendapatkan metode tersebut. Penelitian lain yang mendukung adalah Riefni Riftianingrum (2014) bahwa media permainan alat edukatif berbasis komputer dapat merangsang perkembangan kognitif anak.

Pengajaran dengan menggunakan metode pembelajaran media CD interaktif sangat baik digunakan guru untuk meningkatkan kemampuan kognitif, karena menurut hasil penelitian metode pembelajaran menggunakan $C D$ interaktif lebih baik dibanding dengan metode pembelajaran konvensional. Dalam metode pembelajaran menggunakan CD interaktif anak dapat mengenal konsep bilangan dan memecahkan masalah sederhana.

Dalam hal ini media CD interaktif terbukti memberikan pengaruh yang positif terhadap kemampuan kognitif anak yang merupakan siswa kelompok B2 umar. Selain itu media CD interraktif lebih efisien karena tidak memerlukan alat peraga yang mahal dan memudahkan guru dalam menjelaskan materi sehingga materi yang disampaikan lebih mudah dipahami siswa. Penggunaan media yang tepat atau variatif dapat membantu proses pembelajaran di kelas menjadi lebih menyenangkan. Hal lain yang dapat diamati ialah perubahan kemampuan kognitif siswa yang dipengaruhi oleh media tersebut. Dalam hal ini pengaruh yang terjadi dari penggunaan media yaitu CD interaktif terhadap kemampuan kognitif siswa adalah pengaruh positif. 
"Ceria"

Jurnal Program Studi Pendidikan Anak Usia Dini

Kesimpulan

Berdasarkan hasil penelitian dan pembahasannya, dapat disimpulkan bahwa terdapat perbedaan kemampuan kognitif pada kelompok B yang diberikan metode Berdasarkan analisis terhadap data skor pre-test kemampuan kognitif siswa menunjukkan thitung lebih kecil dari tabel dimana thitung adalah 2,077 dan tabel adalah 2,306 sehingga $H_{o}$ diterima, maka dapat disimpulkan bahwa tidak terdapat perbedaan kemampuan kognitif siswa antara kelompok eksperimen dengan kelompok kontrol. Ini berarti kondisi awal kedua kelas sebelum dilakukan penelitian adalah sama.

Berdasarkan analisis terhadap data skor post-test kemampuan kognitif siswa menunjukkan thitung lebih besar dari tabel dimana thitung adalah 2,834 dan tabel adalah 2,306 sehingga $\mathrm{H}_{a}$ diterima, maka dapat disimpulkan bahwa terdapat perbedaan kemampuan kognitif siswa yang mendapat media CD Interaktif Edukatif dan siswa yang mendapat pembelajaran konvensional. Ini berarti terdapat pengaruh yang signifikan kemampuampuan kognitif siswa antara kelompok eksperimen dan kelompok kontrol.

Berdasarkan pengamatan penulis, pembelajaran kognitif menggunakan media CD Interaktif Edukatif lebih efektif, karena dengan menggunakan media tersebut siswa menjadi lebih memahami dan mengerti mengenai konsep-konsep, dan CD Interaktif Edukatif menjadikan siswa lebih termotivasi dalam belajar.

Dengan adanya temuan penelitian ini yang menyatakan bahwa media CD interaktif dapat meningkatkan kemampuan kognitif siswa, maka berdasarkan temuan ini disarankan dapat digunakan oleh sekolah lain, kepala sekolah dapat memfasilitasi media CD interaktif untuk digunakan sebagai metode belajar oleh para guru.

\section{Daftar Acuan}

Arsyad, Azhar. (2011). Media Pembelajaran. Jakarta: Rajawali Pers.

Daryanto, (2012). Media Pembelajaran. Bandung: Satu Nusa 
"Ceria"

Jurnal Program Studi Pendidikan Anak Usia Dini

Desmita. (2008). Psikologi Perkembangan. Bandung: Remaja Rosdakarya

Ivancevich, John M dkk. (2005). Perilaku dan Manajemen Organisasi. Jakarta: PT. Gelora Aksara Pratama

Montolalu dkk. (2008). Bermain dan Permainan Anak. Jakarta: Universitas Terbuka

Riftianingrum, Riefni. (2014). Pengembangan Alat Permainan Edukatif Berbasis Komputer Untuk Merangsang Perkembangan Kemampuan Kognitif Anak Usia 5-6 Tahun Di Taman Kanak-Kanak. Program Sarjana Teknologi Pendidikan. Skripsi. Jakarta: Universitas Negeri Jakarta.

Robbins, Stephen P dkk. (2008)). Perilaku Organisasi. Jakarta: Penerbit Salemba Empat

Robson, Sue. (2006). Developing Thinking \& Understanding Young Children. New York: Simultaneously published

Sugiyono. (2015). Metode Penelitian Kuantitatif Kualitatif dan RED. Bandung: Alfabeta

Sujiono, Y.N., Tampiomas, E.L, Satriana, M. (2013). Metode Pengembangan Kognitif. Jakarta: Universitas Terbuka

Tingkat Proses kognitif Anak usia Dini di Indonesia. (Nopember 2015) diakses dari http://datatopics.worldbank.org/hnp/file/edstats/IDN10b.pdf 